\title{
Michaelis-Menten Kinetic Parameters of Coconut Coir Enzymatic Hydrolysis
}

\author{
Akbarningrum Fatmawati ${ }^{1}$ \& Rudy Agustriyanto ${ }^{1}$ \\ ${ }^{1}$ Department of Chemical Engineering, the University of Surabaya, Indonesia \\ Correspondence: Akbarningrum Fatmawati, Department of Chemical Engineering, the University of Surabaya, \\ 60284, Indonesia. E-mail: akbarningrum@ubaya.ac.id
}

Received: May 4, 2015

doi:10.5539/mas.v9n7p30
Accepted: June 5, 2015

Online Published: June 30, 2015

\begin{abstract}
The limitation of fossil oil reserves and environmental pollution has been current problems that need to be solved. Biofuels such as ethanol can be alternative energy source that can reduce demand on fossil fuel and environmental problem. Food wastes such as coconut coirs are abundant and contain carbohydrate which can be used as the substrate for biofuel production. Pretreatment and hydrolysis are important stages which have to be applied on such lignocellulose materials before fermentation process to produce biofuel. This article presents Michaelis-Menten kinetic parameters for coconut coir enzymatic hydrolysis. Coconut coirs collected from several local markets in Surabaya were subjected to alkaline pretreatment using 11\% sodium hydroxide solution at $121^{\circ} \mathrm{C}$. Hydrolysis steps were carried out using commercial enzymes at various initial substrate concentrations. The hydrolysis conditions were at $50^{\circ} \mathrm{C}$ and $\mathrm{pH}$ 4.8. The concentrations of reducing sugar produced in the reactions were measured at certain time intervals. Initial rate of reactions of each reaction batch were then determined. Finally, kinetic parameters of Michaelis-Menten model for enzymatic reaction were determined by fitting the initial rate of reactions and initial substrate concentration data. From nonlinear fitting, the maximum reaction rate $\left(V_{m}\right)$ is $4.9 \times 10^{4} 1 / \mathrm{h}$ and the value of $K_{M}$ is $4,195 \mathrm{mg} / \mathrm{L}$.
\end{abstract}

Keywords: hydrolysis, enzyme, kinetic, coconut, cellulase, cellulose

\section{Introduction}

Currently, demand on energy keeps increasing and the supply is mainly from fossil fuel. On the other hand, fossil fuel reserves are limited and hence may not be able to support the increasing energy demand in the future. These problems have been overcome by seeking alternative energy sources that are renewable. The air pollution caused by fossil fuel combustion has added the motive to keep searching the alternative energy sources which are not only renewable but also environmentally friendly as well.

Lignocellulosic biomass is material which is mainly composed of cellulose $40-50 \%$, hemicellulose $25-30 \%$, and lignin $15-20 \%$ (Menon and Rao, 2012). It includes crop residues, grasses, sawdust, wood chips, and solid animal waste (Sun and Cheng, 2002). It is an abundant material on earth and therefore potential to be used to produce low-cost substrate needed in bioethanol production. The cellulose content of lignocellulosic materials can be converted into bioethanol through two processes: hydrolysis and fermentation.

Cellulose hydrolysis is catalysed by cellulase enzyme. It is an enzyme system consisting of three enzymes: exo-1,4- $\beta$-d-glucanases or cellobiohydrolases (CBH) (EC 3.2.1.91), which move processively along the cellulose chain and cleave off cellobiose units from the ends; endo-1,4- $\beta$-d-glucanases (EG) (EC 3.2.1.4), which hydrolyse internal $\beta$-1,4-glucosidic bonds randomly in the cellulose chain; 1,4- $\beta$-d-glucosidases (EC 3.2.1.21), which hydrolyse cellobiose to glucose (Jørgensen et al., 2007). The enzyme works optimally at $\mathrm{pH} 4.8$ and temperature of $50^{\circ} \mathrm{C}$ (Sun \& Cheng, 2002; Fatmawati et al., 2013). As a complex and strong structure, lignocellulose materials can not be degraded readily by the action of cellulolytic enzymes therefore pretreatment is usually needed to have effective enzymatic hydrolysis (Cekmecelioglu \& Uncu, 2013; Sewalt et al., 1997; Kim \& Holtzapple, 2005; Sun \& Chen, 2007). This pretreatment is intended to separate lignin, reduce the cellulose crystallinity, and increase cellulose surface area, which will improve enzyme accessibility (Cekmecelioglu and Uncu, 2013, Dawson and Boopathy, 2007; Jørgensen et al., 2007). There have been many developed methods of pretreatment in the past several decades. Among those methods, acid and alkali pretreatment had been shown to be success (Monschein et al., 2013; Dawson \& Boopathy, 2007; Cara et al., 2008; Yu \& Zhang, 2004). 
Despite many researches on the biomass pretreatment and hydrolysis, only very few publications focused on the coconut coir hydrolysis (Agustriyanto et al., 2012; Fatmawati et al., 2013). Coconut (Cocos nucifera) is an abundant fruit in tropical area, such as in Indonesia. Parts of coconut fruit can be schematically depicted in figure 1. In Indonesia, both young and mature coconuts are commonly consumed. Young coconuts water and meat are consumed as beverages while old coconut milk is extracted from the meats to prepare certain meals. Consumption of coconuts leaves piles of wasted pericarps. The pericarp of young coconut fruits is composed of green exocarp with white, softer and moister mesocarp, while that of old coconut is composed of brown exocarp with brown, stiffer and drier mesocarp. Although the wasted pericarps of old coconut have been used to make certain products such as floor mats, brushes, car seat filler and mattresses, in large local markets, a huge pile of wasted coconut pericarp is still frequently found. Burning such materials is not only useless but can also release large carbon into atmosphere. Therefore in this research we used old coconut coir for cellulose source to produce sugar through enzymatic hydrolysis.

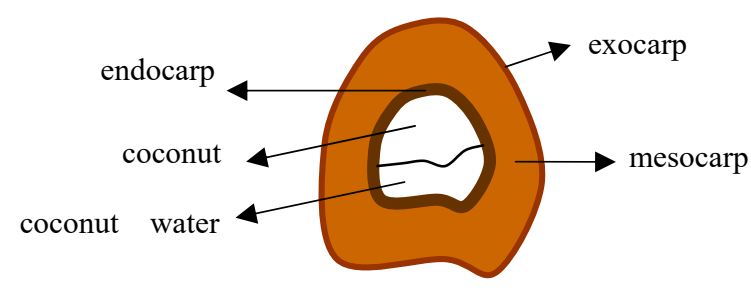

Figure 1. Schematic illustration of coconut fruit parts

Kinetic models are important for chemical and biochemical processing. They describe process performance and can be used to control and predict process variables. Kinetic models of several lignocellulosic biomass enzymatic hydrolysis had been published. However, none of them had discussed the kinetic model of coconut coir hydrolysis. A well-known kinetic model for enzymatic reaction is Michaelis-Menten model as follows [Lee, 1992]:

$$
r=\frac{V_{m}[S]}{K_{M}+[S]}
$$

Where: $\mathrm{r} \quad=$ hydrolysis reaction rate, $\mathrm{mg} / \mathrm{L} . \mathrm{h}$

$\mathrm{V}_{\mathrm{m}}=$ maximum forward hydrolysis reaction rate, $1 / \mathrm{h}$

$\mathrm{K}_{\mathrm{M}}=$ Michaelis-Menten constant, $\mathrm{mg} / \mathrm{L}$

[S] = Susbtrate conecentration, $\mathrm{mg} / \mathrm{L}$

Where rate of reaction $(r)$ can be determined from rate of substrate or product concentration change:

$$
r=\frac{d[P]}{d t}=-\frac{d[S]}{d t}
$$

Where: $[\mathrm{P}] \quad=$ product concentration, $\mathrm{mg} / \mathrm{L}$

$\mathrm{t} \quad=$ hydrolysis time, $\mathrm{h}$

Many other forms of kinetic models have been used to describe cellulose and lignocellulosic biomass enzymatic hydrolysis. In this paper, Michaelis-Menten kinetic model is adopted to represent coconut coir enzymatic hydrolysis. The cellulose content of coconut coirs and the reducing sugar produced from the reaction will represent the substrate and product, respectively.

\section{Method}

\subsection{Materials}

Coconut pericarps were collected from several local markets. Immediately after collection, the material was soaked in water for 24 hours. After immersion, the exocarp part was easily pulled out from the fibrous coir or mesocarp. The coir was then sun-dried. The dry coir was then cut into $\pm 5 \mathrm{~cm}$ long and milled using disc mill machine (FFC type 23A with rotation velocity of $5800 \mathrm{rpm}$ and power of $3 \mathrm{~kW}$ ). Fine particles of coconut coir with size of 200 meshes were collected by screening the milled coconut coir. In this research, two commercial 
cellulase enzymes were used: Celluclast ${ }^{\circledR}$ 1.5L (Sigma Aldrich) and Novozyme 188 (Sigma Aldrich). The cellulose powder used for FTIR spectra comparison was microcrystalline cellulose powder (Sigma Aldrich).

\subsection{Coconut Coir Pretreatment}

Coconut coir particles were pretreated using $11 \% \mathrm{NaOH}$ solution in autoclave at $121^{\circ} \mathrm{C}$ for 1 hour. The solid concentration at pretreatment was $7.5 \% \mathrm{w} / \mathrm{v}$. The pretreatment conditions used were based on the previous optimum result obtained from coconut coir alkaline pretreatment (Fatmawati et al., 2013). The pretreated particles were washed and filtered until the filtrate achieved neutral $\mathrm{pH}$. Then the particles were oven-dried and ready for weighing.

\subsection{Enzymatic Hydrolysis}

The hydrolysis reactions were carried out in a series of $250 \mathrm{~mL}$ Erlenmeyer flasks with working volume of 100 $\mathrm{mL}$. The $\mathrm{pH}$ of reaction systems were adjusted 4.8 using sterile sodium citrate buffer. The reaction temperature was kept at $50^{\circ} \mathrm{C}$ by placing the flasks in a incubator shaker equipped with temperature control. Agitation was provided by shaker at rotation velocity of $150 \mathrm{rpm}$ (Ye \& Berson, 2011).

The concentrations of coconut coir slurry were varied at $0.1,0.2,0.4,1.0$, and $2.0 \mathrm{~g} / 100 \mathrm{~mL}$. The reaction time was varied at $2,4,6,8,12,16,24,36,48$, and 72 hours. The volumes of enzyme added were $0.33 \mathrm{~mL}$ Celluclast ${ }^{\circledR}$ and $0.33 \mathrm{~mL}$ Novozyme 188. Each of reaction conditions was carried out in triplicates. In order to prevent microbial contamination during hydrolysis, $40 \mathrm{mg} / \mathrm{mL}$ tetracycline antibiotic was added to the flask. At the end of reaction, the flasks were immersed in $95-100^{\circ} \mathrm{C}$ water to inactivate the enzymes prior to analysis.

\subsection{Chemical Analyses}

The concentrations of reducing sugar produced from hydrolysis reactions were analysed using 3,5-dinitrosalicylic acid (DNSA) reagent (Miller, 1959). The cellulose and lignin contents of pretreated coconut coir were analysed using Chesson method (Datta, 1981). FTIR analysis was done using Bruker Tensor 27 FTIR Spectrometer and the spectra were recorded at normal IR range 4000-400 $\mathrm{cm}^{-1}$.

\subsection{Michaelis-Menten Kinetic Parameters}

Five sugar concentration versus reaction time data at five different initial coir slurry concentrations were obtained after chemical analysis. The sugar concentrations versus times data were empirically fitted and initial reaction rates were then determined by differentiating the fitted correlations at initial condition. Parameters of Michaelis-Menten which are $V_{m}$ and $K_{M}$ were then obtained by nonlinear fitting the initial reaction rates versus initial cellulose concentrations data.

\section{Results and Discussion}

Previous publication showed that coconut coir contains $41.7 \%$ cellulose and lignin $30.54 \%$ (Fatmawati et al., 2013). After alkaline pretreatment had been applied to the coconut coir at $121^{\circ} \mathrm{C}$ in autoclave, the cellulose content increased into $48.75 \%$ and the lignin content decreased into $28.42 \%$. The presence of cellulose, hemicelluloses, and lignin in raw and pretreated coconut coir is depicted on FTIR spectra shown in Figure 2B and Figure 2C which are compared to those of cellulose powder shown in Figure 2A. Based on studied publication (Stewart et al., 1995, Pandey, 1999, Liu \& Wyman, 2004, Kahar, 2013), the presence of cellulose is shown from band position $897-1430 \mathrm{~cm}^{-1}$. The $\mathrm{CO}_{2}$ stretching of carboxylic acid group in cellulose is shown at the band position of $1431.44,1451.07$, and $1424.67 \mathrm{~cm}^{-1}$ at the spectrum of cellulose powder (Figure 2A), raw coconut coir (Figure 2B), and pretreated coconut coir (Figure 2C), respectively. The band position 897-900 $\mathrm{cm}^{-1}$ indicates the presence of amorphous cellulose while that at $1109-1098 \mathrm{~cm}^{-1}$ indicates C-O vibration of crystalline cellulose. It can be seen that the pretreatment of raw coconut coir can raise the amorphous part of cellulose by comparing Figure 2B and Figure 2C. The band position at $1735.11 \mathrm{~cm}^{-1}$ shows the linkage of lignin side chain with branched hemicelluloses in raw coconut coir (Figure 2B). This band does not exist in cellulose powder (Figure 2A) and pretreated coconut coir (Figure 2C) where the pretreatment process to produce cellulose may break down the hemicelluloses content of the material. The aromatic part of lignin is indicated at the band position of 1512-1650 $\mathrm{cm}^{-1}$. This part of lignin arises in cellulose powder, raw coconut coir and pretreated coconut coir.

The data obtained from the coconut coir hydrolysis experiment is presented in Figure 3. The initial coconut coir slurry concentrations thus can be converted into cellulose (substrate) initial concentration using this composition percentage. The result depicted in Figure 3 showed that the higher initial coconut coir slurry concentration, the higher the reducing sugar concentration obtained. The highest reducing sugar concentration was $1,049 \mathrm{mg} / \mathrm{L}$ which was resulted from initial coconut coir concentration of $2.0 \mathrm{~g} / 100 \mathrm{~mL}$ after $72 \mathrm{~h}$ hydrolysis. It also shows 
that the higher initial substrate concentration the steeper the gradient line at initial time, therefore the higher initial reaction rate is. The gradients of reaction rate curves at initial conditions were used to determine initial rates for each initial substrate concentration.

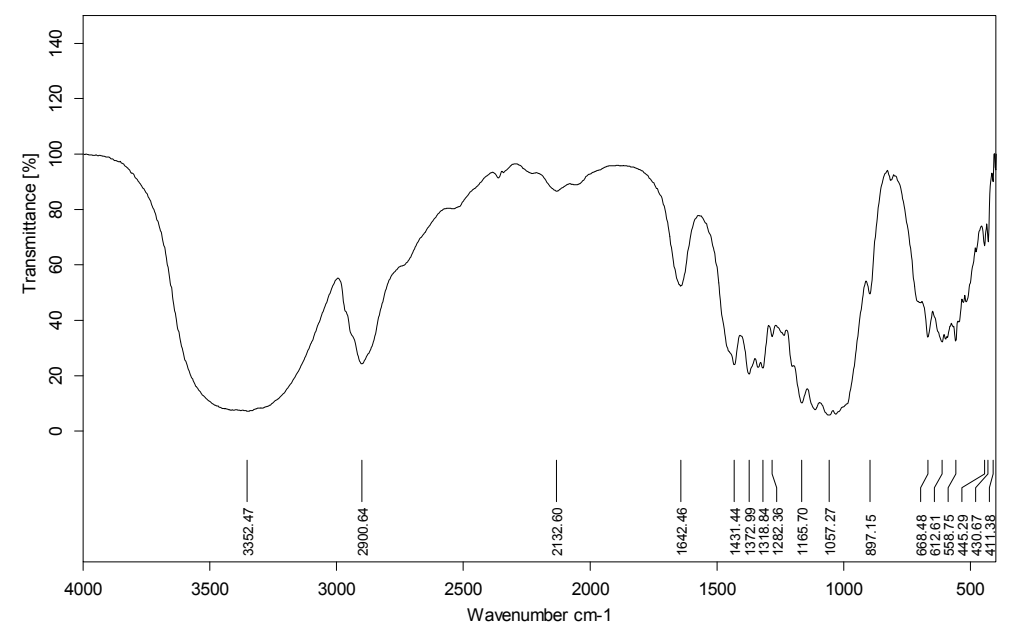

$\mathbf{A}$

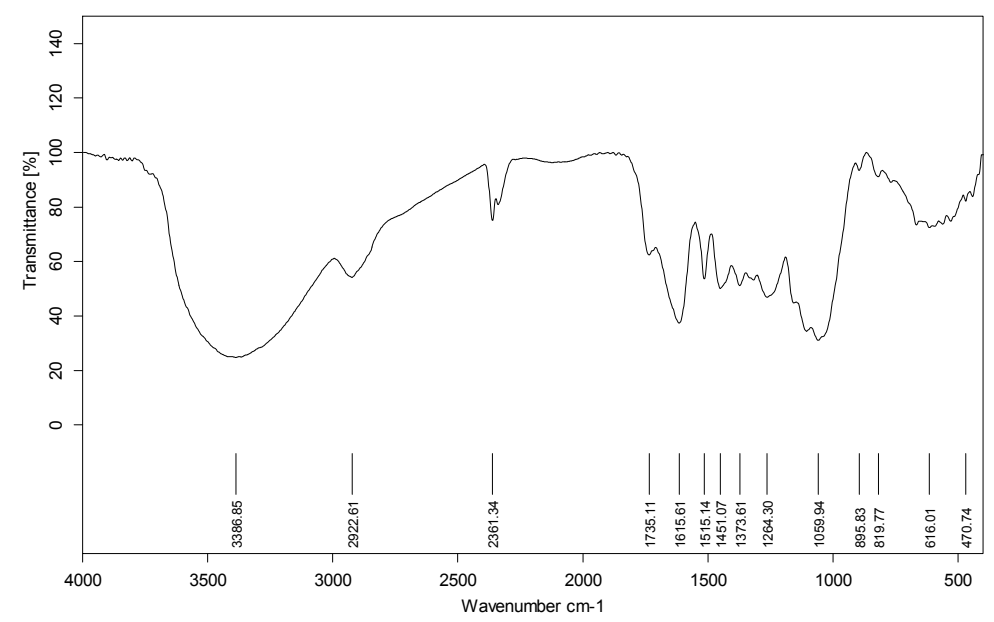

B

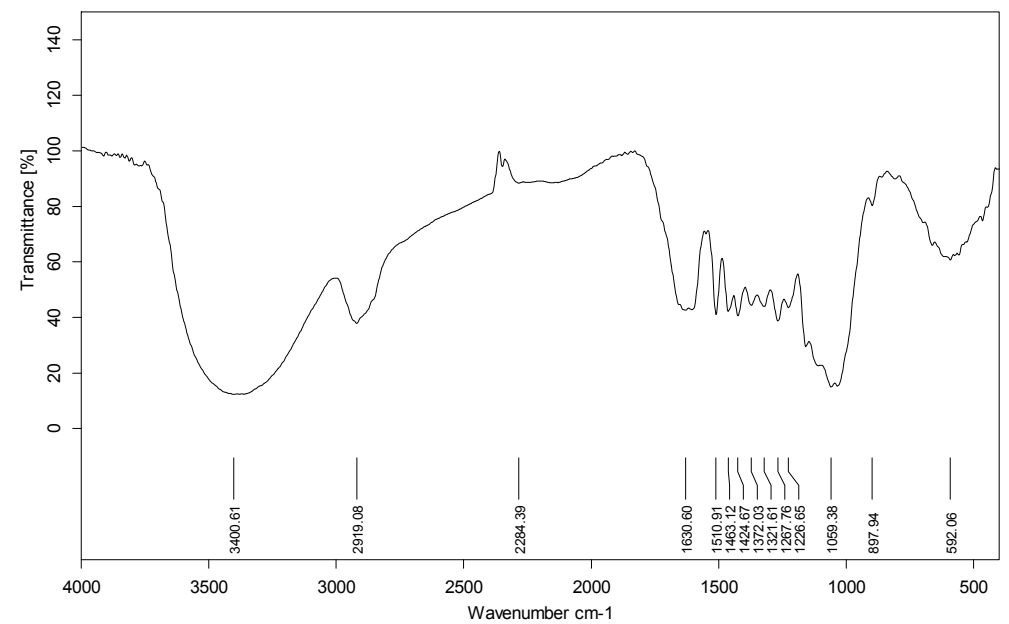

C

Figure 2. FTIR spectra of (A) cellulose powder (Sigma Aldrich), (B) raw coconut coir, (C) pretreated coconut coir 


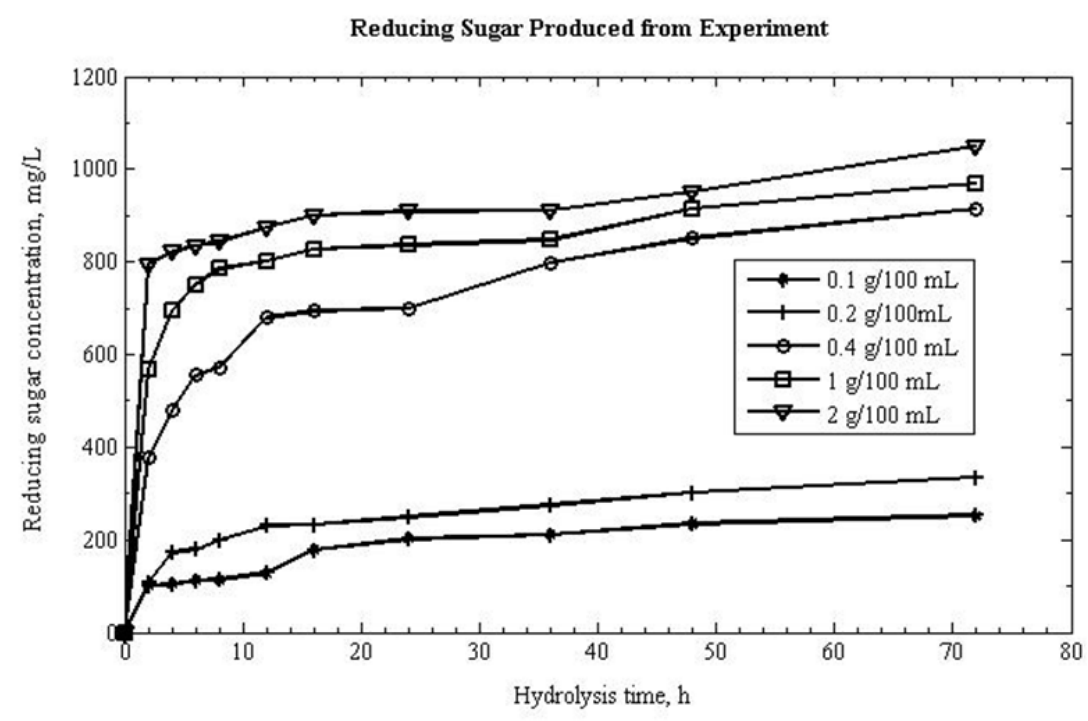

Figure 3. Reducing sugar concentration produced from experiment

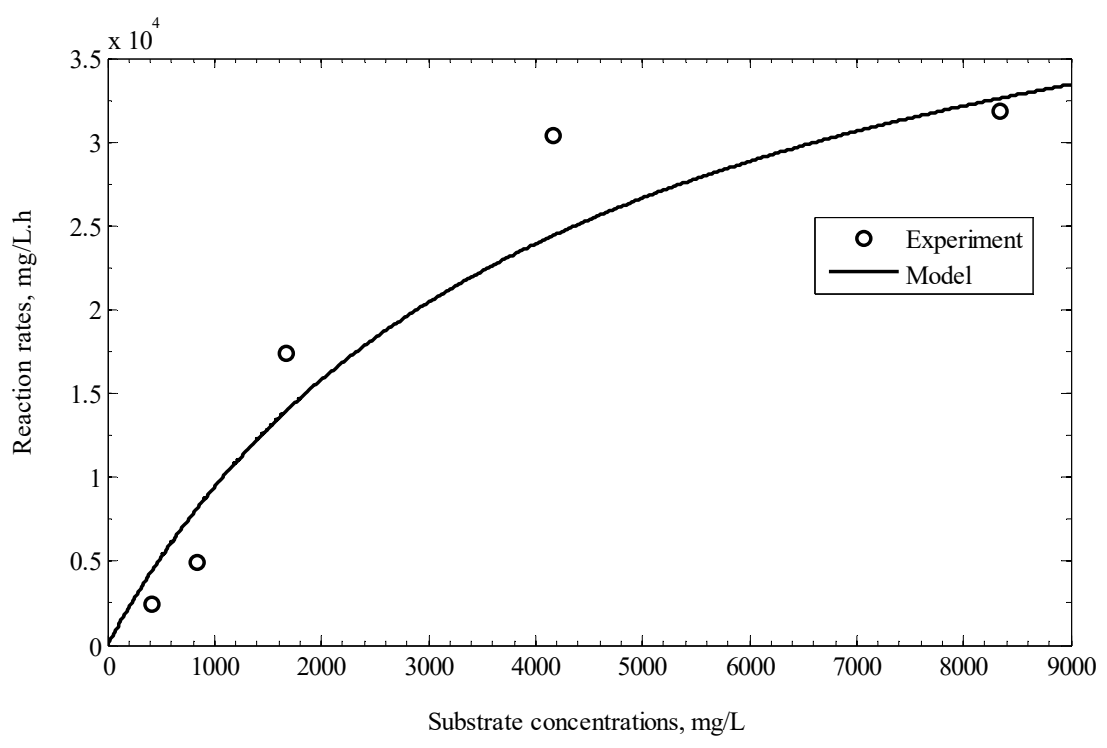

Figure 4. Reaction rate curve of coconut coir enzymatic hydrolysis

The kinetic parameters were obtained from non-linear curve fitting of initial rate versus initial cellulose concentration data. The values are presented in Table 2. Using the values of $\mathrm{V}_{\mathrm{m}}$ and $\mathrm{K}_{\mathrm{M}}$, the rate of reaction versus substrate concentration can be plotted and presented in Figure 4. It can be seen that the model can represent the experimental data quite good with correlation coefficient $\left(R^{2}\right)$ equals to 0.932 as shown in Table 1. Previous research on enzymatic hydrolysis of microcrystalline cotton cellulose by cellulase enzyme from $T$. reesei showed values of $\mathrm{V}_{\mathrm{m}}$ of 4,560-18,240 1/h and $\mathrm{K}_{\mathrm{M}}$ of 1,839-9,844 $\mathrm{mg} / \mathrm{L}$ (Yeh et al, 2010).

Table 1. Kinetic Parameters of Coconut coir enzymatic hydrolysis

\begin{tabular}{llc}
\hline Kinetic Parameters & Values from & $\begin{array}{r}\text { Non Linear Fitting } \\
\left(\mathrm{R}^{2}=0.932\right)\end{array}$ \\
\hline $\mathrm{V}_{\mathrm{m}}$ & $4.9 \times 10^{4}$ & $1 / \mathrm{h}$ \\
$\mathrm{K}_{\mathrm{M}}$ & 4,195 & $\mathrm{mg} / \mathrm{L}$ \\
\hline
\end{tabular}




\section{Acknowledgments}

This work was funded by Directorate General of Higher Education Indonesia through Decentralized Fundamental research scheme with contract no. 002/Lit/LPPM/Dikti/FT/IV/2014. The authors thank to the University of Surabaya (Ubaya) for the support in conducting this research.

\section{References}

Agustriyanto, R., Fatmawati, A., \& Liasari, Y. (2012). Study of enzymatic hydrolysis of dilute acid pretreated coconut husk. Bulletin of Chemical Reaction Engineering and Catalysis, 7(2), 137-141. http://dx.doi.org/10.9767/bcrec.7.2.4046.137-141

Cara, C., Ruiz, E., Oliva, J. M., Sáez, F., \& Castro, E. (2008). Conversion of olive tree biomass into fermentable sugars by dilute acid pretreatment and enzymatic saccharification. Bioresource Technology, 99, 1869-1876.

Cekmecelioglu, D., \& Uncu, O. N. (2013) Kinetic modeling of enzymatic hydrolysis of pretreated kitchen wastes for enhancing bioethanol production. Waste Management, 33, 735-739. http://dx.doi.org/10.1016/j.wasman.2012.08.003

Datta, R. (1981). Acidogenic fermentation of lignocellulose-acid yield and convertion of component. Biotechnology and Bioengineering, 23, 2167-2170.

Dawson, L., \& Boopathy, R. (2007). Use of post-harvest sugarcane residue for ethanol production. Bioresource Technology, 98, 1695-1699.

Fatmawati, A., Agustriyanto, R., \& Liasari, Y. (2013). Enzymatic hydrolysis of alkaline pretreated coconut coir. Bulletin of Chemical Reaction Engineering and Catalysis, 8(1), 34-39. http://dx.doi.org/10.9767/bcrec.8.1.4048.34-39

JØrgensen, H., Kristensen, \& J.B., Felby, C. (2007). Enzymatic conversion of lignocellulose into fermentable sugars: challenges and opportunities. Biofuels, Bioproduction and Biorefining, 1, 119-134.

Kahar, P. (2013). Synergistic effects of pretreatment process on enzymatic digestion of rice straw for efficient ethanol fermentation. In M. Petre (Ed.), Environmental Biotechnology-New Approaches and Prospective Applications (pp. 73-77), InTech. http://dx. doi.org /10.5772/56068

Kim, S., \& Holtzapple, M. T. (2005). Lime pretreatment and enzymatic hydrolysis of corn stover. Bioresource Technology, 96, 1994-2006.

Lee, J. M. (1992). Biochemical Engineering. New Jersey:Prentice-Hall International Inc.

Liu, C. G., \& Wyman, C. E. (2004). Impact of fluid velocity on hot water only pretreatment of corn stover in a flow through reactor. Applied Biochemistry and Biotechnology, 115(1-3), 977-987.

Menon, V., \& Rao, M. (2012). Trends in bioconversion of lignocellulose: biofuels, platform chemicals, and biorefinery concept. Progress in Energy and Combustion Science, 38, 522-550. http://dx.doi.org/10.1016/j.pecs.2012.02.002

Miller, G. L. (1959). Use of dinitrosalicylic acid reagent for determination of reducing sugar. Analytical Chemistry, 31, 426-428.

Pandey, K. K. (1999). A Study of chemical structure of soft and hardwood and wood polymers by FTIR spectroscopy. Journal of Applied Polymer Science, 71, 1969-1975.

Sewalt, V. J. H., Glasser, W. G., \& Beauchemin, K. A. (1997). Lignin impact on fiber degradation: reversal of inhibition on enzymatic hydrolysis by chemical modification of lignin and by additives. Journal of Agricultural and Food Chemistry, 45, 1823-1828.

Stewart, D, Wilson, H. M, Hendra, P. J., \& Morrison, I. M. (1995). Fourier-transform infrared and Raman-spectroscopic study of biochemical and chemical treatments of oak wood (Quercus rubra) and barley (Hordeum vulgare) straw. Journal of Agricultural and Food Chemistry, 43, 2219-2225.

Sun, F. B., \& Chen, H. Z. (2007). Evaluation of enzymatic hydrolysis ofwheat straw pretreated by atmospheric glycerol autocatalysis. Journal of Chemical Technology and Biotechnology, 82, 1039-1044.

Sun, Y., \& Cheng, J. (2002). Hydrolysis of lignocellulosic materials for ethanol production: a review. Bioresource Technology, 83, 1-11.

Ye, Z., \& Berson, E. (2011). Kinetic modeling of cellulose hydrolysis with first order inactivation of adsorbed cellulose. Bioresource Technology, 102, 11194-11199. 
Yeh, A. I., Huang, Y. C., \& Chen, S. H. (2010). Effect of particle size on the rate of enzymatic hydrolysis of cellulose. Carbohydrate polymers, 79, 192-199. http://dx.doi.org/10.1016/j.carbpol.2009.07.049

Yu, Z., \& Zhang, H. (2004). Ethanol fermentation of acid-hydrolyzed cellulosic pryolysate with Saccharomyces cerevisiae. Bioresource Technology, 93, 199-204. http://dx.doi.org/10.1016/j.biortech.2009.05.049

\section{Copyrights}

Copyright for this article is retained by the author(s), with first publication rights granted to the journal.

This is an open-access article distributed under the terms and conditions of the Creative Commons Attribution license (http://creativecommons.org/licenses/by/3.0/). 